\title{
Malinka Pila*
}

\section{Slavic Alpine micro-varieties as part of an "Alpensprachbund"?}

\section{The case of the venitive (come) passive}

https://doi.org/10.1515/stuf-2021-1027

Received January 10, 2020; accepted July 15, 2020

\begin{abstract}
This chapter deals with some characteristics of two more-or-less isolated Slavic varieties in the south-eastern Alps: Resian and Carinthian Slovene, whose nearest relative among the Slavic standard languages is Slovene. Both have been for centuries in situations of total language contact with Romance and Germanic varieties. I will concentrate on the come passive. At least in Resian, it developed due to direct Romance influence, which could be claimed to be the overall reason for this grammatical feature in the Alps. The situation in Molise Slavic in southern Italy will serve as a point of comparison.
\end{abstract}

Keywords: Carinthian Slovene; language contact; Molise Slavic; Resian; venitive passive

\section{Introduction}

The venitive passive, formed with the auxiliary 'to come' + passive participle, has been claimed to be an important feature of the assumed "Alpensprachbund" (Alpine linguistic area), uniting languages of three different language families, Germanic, Romance and Slavic. This chapter addresses two Slavic micro-languages in the southeastern Alps, Carinthian Slovene in Austria and Resian in Italy, both of them in situations of total language contact with dominant majorities of two other groups Germanic and Romance varieties, respectively. Its main goal is to show the extent and the role of the venitive passive in Resian, as well as its development under the influence of the surrounding Romance languages in north-eastern Italy, Friulian and also Italian, both in its standard and its regional Venetian variety. A short description of the situation in Carinthian Slovene, the neighboring Alpine dialects of German (Bavarian and Alemannic), and in other Rhaeto-Romance languages besides Friulian will give further insight into this rather complex question of the emergence of a common linguistic phenomenon across language borders, typical for a "Sprachbund".

*Corresponding author: Malinka Pila, Department of Linguistics, University of Konstanz, Germany, E-mail: malinka.pila@uni-konstanz.de 


\section{General remarks: passive constructions and their distribution}

Before discussing Slavic minority languages in the south-eastern Alps and beyond, I will briefly deal with the general distribution of the venitive passive in Alemannic and Bavarian, as this has been the starting point for previous scholars to postulate the venitive passive as a specific linguistic feature of the Alpine area. I will start with the question of potential "gaps" in the grammar of Romance, Germanic and Slavic languages, favoring the development of a new passive besides the existing ones.

\subsection{Eventive and stative passives in Italian, German and Slavic}

The essential gap in the field of passives in the history of the Germanic, Romance and Slavic languages derives from the ambiguity of the existing esse passive, formed by means of the auxiliary 'to be' + past participle, originally functioning both as a stative passive (Zustandspassiv) and an eventive (action) passive (Vorgangspassiv), illustrated by the English examples in (1).

(1)

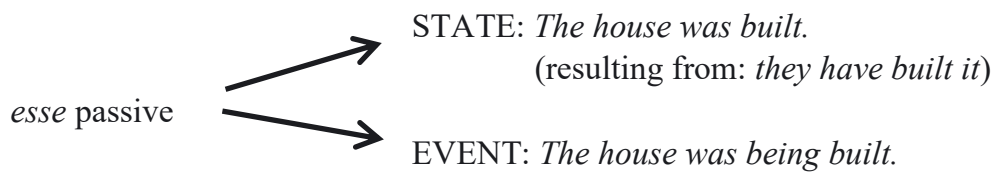

In Slavic languages, for example in Russian, this ambiguity has been partially resolved through the expression of the eventive passive by means of the reflexive passive, formed with the help of the reflexive particle -sja, as in (2a). But this possibility is restricted to verbs in the imperfective aspect (processes and iterations), while for perfective verbs (completed single states of affairs) the ambiguity continues to exist - see ( $2 b)$. The Russian examples in $(2 a / b)$ correspond to the English ones in (1). Both constructions in (2) allow for an agent, for example $\operatorname{mnoj}(u)$ 'by me', expressed by the instrumental. ${ }^{1}$

\footnotetext{
1 In standard Slovene, too, both constructions are possible. But here the reflexive construction, which just like in Russian is restricted to the eventive passive but, unlike in Russian, does not admit an agent, combines both with imperfective verbs, expressing ongoing processes or iterated events, and with perfective ones, conveying single completed actions or iterated situations. Especially in the past and future tenses the esse passive shows ambiguity between stative and eventive passive, like in Russian. For more information about the passive in Slovene see for instance Bajec et al. (1971: 252-257) and Herrity (2000: 161-163, 194-198); for a comparison with Russian and Resian see Pila (2019).
} 
(2a) reflexive passive

EVENT: Dom stroilsja. IPFV.PAST.REFL.3SG

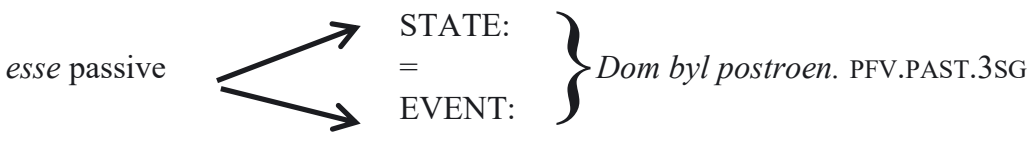

In Italian there is a reflexive passive for rendering events, too. Contrary to Russian, however, adding an explicit agent is excluded (3a). The esse passive is again ambiguous, though with a preference for the expression of states in the present. In the past tense there is an aspectual differentiation, with the imperfect referring to states and the perfect (passato prossimo) referring to events ( $3 \mathrm{~b}$ ). But in the present (and in the imperfect), processual and habitual eventive meanings are not excluded, though they are mostly avoided by speakers. ${ }^{2}$

Here, the development of a venitive passive as in (3c) had a double advantage. In the first place, it was an unambiguous way of expressing the eventive passive, just like the reflexive passive, and on the other hand it allowed for the addition of an agent like da me 'by me', excluded in the reflexive passive. So, there was enough internal motivation for developing a venitive passive in Italian and, indeed, it is used frequently in spoken and written Italian. ${ }^{3}$

reflexive passive (no agent)

(3b)

(3c)

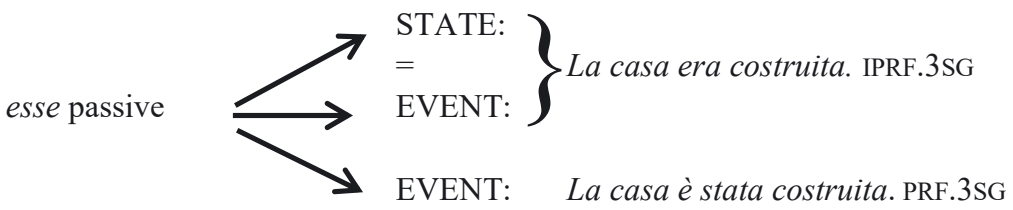

La casa si costruiva. IPRF.REFL.3SG

La casa si è costruita. PRF.REFL.3SG

$$
\begin{array}{r}
\text { (3c) } \quad \text { (positive passive } \\
\text { (pole agent) }
\end{array}
$$

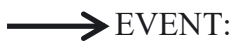

2 The usage of the esse passive in Italian is rather complex, but is mostly irrelevant for the discussion in this chapter. For more details see, for example, Thieroff (1994: 42-45) and, for a comparison with the equivalent construction in Molise Slavic, Breu and Makarova (2019).

3 For more details on the origin of the venitive passive in Italian see Rohlfs (1969: 128-129); for its meaning and use in contemporary Italian see, for instance, Giacalone Ramat (2000; 2017), Giacalone Ramat and Sansò (2014), Lepschy and Lepschy (1977: 141), Salvi and Vanelli (2009: 70), Schwarze (2009: 142-143), and Serianni (1988: 326-327). 
Comparing Italian to Russian, different paths have been taken to disambiguate the eventive passive from the stative passive, traditionally combined in the esse passive construction. While Russian allows for a reflexive passive with an agent, the reflexive passive in Italian does not permit an explicit agent. This is a disadvantage supporting the grammaticalization of the venitive passive, specialized in the expression of events, whose agent may formally be expressed. Now let us examine the other languages in the Alpine area and their behavior with respect to the role of the venitive passive.

\subsection{The venitive passive in Alpine Bavarian and Alemannic}

First of all, the venitive passive, mentioned by Lessiak (1903) for Carinthian Bavarian, is rare. Already in 1989, only elder people still remembered its higher frequency in the past (Wiesinger 1989). The venitive passive either entered southern Carinthian by direct contact with the Romance population in the border area, or developed due to the contact with Italian immigrants, especially in the city of Villach, or with Italian merchants passing through. The same is true for other south Bavarian varieties outside the areas of modern language contact with Romance, especially in eastern Tyrol. There is no venitive passive either in Tyrol proper or in any of the many remaining varieties of Bavarian, Alpine or otherwise.

In Bavarian-based linguistic islands (enclaves), on the other hand, the venitive passive is frequent, normally with the same variation and distribution of its counterpart, the esse passive (like in Italian). The same seems to be true for the Alemannic-based Walser dialects further to the west (Gaeta 2018).

As for Alemannic, the venitive passive is much more widespread outside the areas of modern language contact, for example in the Valais. We even find the opposite development, that is, a stable usage of the venitive passive (like in Romansh) with the German werden passive gradually creeping in (Bucheli Berger 2005).

A reasonable explanation for this difference between Alemannic and Bavarian may be found in the hypothesis that, in south Alemannic dialects, the German werden passive had not yet developed when they came into contact with Romance varieties. So either the Romance venitive passive was copied in south Alemannic or - less probably - it developed in both contexts more-or-less independently at the same time. It could then spread even into some northern conservative dialects. In Bavarian this was not the case, as the werden passive apparently developed here very early. Thus, the venitive passive of the Romance varieties with which southern Bavarians came into contact could only become optional, as the original ambiguous passive, formed with the auxiliary sein 'to be', had already been replaced by 
the werden passive as an eventive passive, thus being reduced to its function as a stative passive. ${ }^{4}$

If this is true, in Alemannic the intruder is the werden passive, whereas in Bavarian it is the come passive. As both auxiliaries served to form the eventive passive, the position of the come passive, only doubling the existing werden passive, where it existed, was rather weak and could easily be given up again, when and where Romance influence diminished.

Given the linguistic data about the existence or rather the non-existence of the come passive in most parts of Bavarian, it is a strange phenomenon in linguistic typology that Bavarian is more often cited as having a venitive passive than Alemannic. In part, this is certainly due to Mayerthaler (1986) and Mayerthaler and Mayerthaler (1990: 390) claiming the venitive passive as one of the Romance characteristics of south Bavarian. The real problem, however, is that their followers, whose works commonly copied Mayerthaler's (1986) example, often without citing the source, omitted the restriction to "south" Bavarian; furthermore, they ignored Wiesinger's (1989) criticism of Mayerthaler (1986) for attributing usage of the venitive passive to south Bavarian as a whole, when it is actually restricted to the extreme south, more precisely East and South Tyrol and southern Carinthia, far away from the central Alps. ${ }^{5}$

Here are some of the steps by which Bavarian came to be seen as a "typical example" of the venitive passive, promoting the myth of an Alpine passive:

- Mayerthaler (1986) claims that in "south Bavarian", in addition to the passive with the auxiliary werden, there exists a passive with the auxiliary kommen that emphasizes more strongly a sense of process, like in the example "Då kummt de nei(e) Schul gebaut" 'The new school is being built', corresponding to Italian "Qui viene costruita la nuova scuola”.

- $\quad$ Ramat (1998: 227), however, in using the same example, crucially expands this statement to encompass Bavarian as a whole: "The Bavarian variety of High German has a periphrastic passive formed by the auxiliary kommen 'come' (instead of standard German werden)". For him this construction is "strongly reminiscent of the Romance passive with venire", being the rule in Rhaeto-

4 My thanks go to Walter Breu, Konstanz, for communicating this hypothesis to me, which is difficult to confirm on the basis of Old High German data, but which seems reasonable based on the effects of these presumed situations of language contact. For a short discussion on the existing hypotheses about the development of a venitive passive in German varieties, see Bellmann (1998: 241-243). As for the rise of the werden passive in German, see Thieroff (1994: 51), Dal and Eroms (2014: 147-151), Vogel (2014: 119-225), and Kotin (1998).

5 Given these facts, even the restriction given by Mayerthaler et al. (1995: 39), with reference to Carinthia and Tyrol as a whole, is not strong enough: "Es ist allerdings darauf hinzuweisen, daß die Heterogenität des Bairischen in vielen der erwähnten Subbereiche keine Verallgemeinerungen zuläßt, so ist z.B. das kommen-Passiv typisch für das Südbairische (in Kärnten und Tirol) ...”. 
Romance (Ladin), and calls it an "easy guess that the Romance type has influenced the geographically contiguous Bavarian passive" due to "the historical contacts between South Germany and North-East Italy”, which certainly existed, but are irrelevant in the given case. In this way, a phenomenon clearly restricted to the southernmost periphery of Bavarian in the Alps was connected with southern Germany (and Bavarian as a whole), where the venitive passive does not actually exist at all.

- Heine and Kuteva (2010: 97), in citing Ramat's (1998: 227-228) discussion of Mayerthaler's (1986) example, repeat his argumentation about the distribution of the come passive in "the Bavarian dialect of German" being due to the contact between southern Germany and northern Italy.

- Wiemer (2011), in the Oxford handbook of grammaticalization online, referring again to Ramat (1998), then simply speaks of the 'Alpine passive', without further discussion.

- Heine (2014: 772) repeats Mayerthaler's (1986) example once again, translating it, however, less specifically as 'Here the new school is constructed'. He again simply speaks of "the Bavarian dialect of German" without any hint at the strong restriction of the venitive passive to the extreme south, which excludes most parts of the Bavarian and Austrian Alps.

As an intermediate result, we have to underline that Bavarian, unlike Alemannic, only very marginally contributes to a hypothetic Alpine venitive passive, as it is restricted to the southern and western parts of the Alps and to the linguistic enclaves further to the south. Nevertheless, the chain of citations, coupled with a neglect of the real data and a failure to take Wiesinger's (1989) findings seriously, has ensured that linguistic research on Bavarian as a whole - that is, including the dialects spoken in the central and northern Alpine areas - has come to be haunted by the venitive specter.

\section{The venitive passive in Slavic micro-languages}

A presentation of the data on Germanic and Romance varieties in the western and southern Alps is not sufficient to allow a judgment on the overall characteristics of the venitive passive with respect to its possible role in an "Alpensprachbund", as Slavic varieties in- and outside the Alpine area may also contribute to a solution. Therefore, the following deals with the question of a venitive passive in three Slavic minority languages in situations of strong language contact, Carinthian Slovene, Resian and Molise Slavic, of which the first two are spoken in the southern Alps and the last in southern Italy. 


\subsection{The venitive passive in Carinthian Slovene}

Carinthian Slovene is spoken in the southern part of the Austrian federal state of Carinthia, bordering with Slovenia and Italy, with four main dialect areas, Gailtal in the west, Rosental in the center, Jaun in the east and Obir in the extreme southeast; see, for example, map 1 in Pronk (2009: VIII). By now, all Carinthian Slovenes are bilingual with German as their umbrella language, while standard Slovene is mainly restricted to schooling, some cultural activities and interactions with Slovene tourists and official representatives. ${ }^{6}$ Only in the Gailtal region is there also direct contact with Italian.

As for the passive, Carinthian Slovene had even in ancient times already replaced the former esse passive in its eventive function by a bo passive, that is, one formed with the traditional future auxiliary. There is no doubt that this was due to the German model of the auxiliary werden, serving to express both the future and the passive. Thus, there was an "adaptation of the semantic structure" by means of copying the polysemy of the model language. ${ }^{7}$ So, unlike in standard Slovene, a traditional future of the type bo + passive past participle (=PPP) 'he will be + PPP' also means 'he is (being) + PPP' in Carinthian Slovene, like in the following example Jesus bo v'grob poloshen. = Jesus is (being) put into the grave. $^{8}$

On the other hand, the venitive passive in Carinthia is restricted to the southwestern-most parts, in the valley of the river Gail, where direct contact with Romance was possible. Indirect evidence for this claim is provided by the example given by Isačenko (1939), see (4) below, taken from the western dialect of the Gailtal region (although his book focuses on the central Rosental dialect). So, it is no wonder that my informants ${ }^{9}$ from Slavic locations further to the east did not accept a venitive passive at all. The often-cited example (4) from Isačenko (1939: 119-120) contains only one venitive passive, prîdə farlọdan

6 The linguistic and political situation in Carinthia, being rather complex and controversial due to the situation post-World War I and the different attitudes of the speakers towards their heritage, cannot be presented here in any detail. For more information see, for instance, Jodlbauer (1996: especially 124-129) and Maurer-Lausegger (1992).

7 This type of semantic calque is a very important way of leveling out differences in the lexicon and the grammar of languages in contact. For further details see, for example, Breu (2003).

8 This example, reported here in its original orthography, is taken from the 14th station of the Via Crucis in the Prämonstratenser-Chorherrenstift St. Maria in Griffental (Carinthia).

9 My direct information goes back to a short field research campaign in Carinthia in May 2017, dedicated mainly to investigations in the domain of verbal aspect. I am grateful to several colleagues from the University of Klagenfurt for bringing me into contact with Carinthian-Slovene informants and to these informants themselves for their patience in responding to a questionnaire. 
(come:PFV.PRS.3SG + load:PPP.NOM.SG.M) 'will be loaded', contrary to Wiesinger's (1989) claim that the second bo construction of this sentence is a come passive. Both bo passives and the intermediate come passive are in bold type. ${ }^{10}$

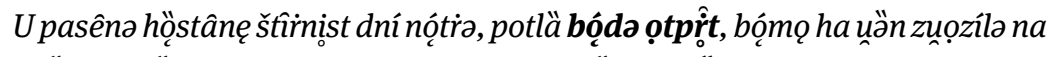

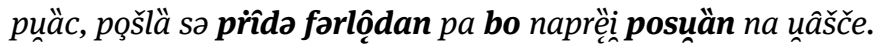

'It remains in the basin for 14 days, then it will be opened, then we will carry it out to the square, then it comes loaded (will be loaded, is usually loaded), then it will be sent further to Italy.'

The two existing descriptions of the western Gailtal dialect, Pronk (2009) and Neweklowsky (2013), make no mention of a venitive passive at all. There is, however, another productive auxiliary used for expressing the eventive passive, besides the future auxiliary bo, namely grotato, from German geraten 'get into' (Neweklowsky 2013: 125). This seems an autonomous development, and this auxiliary is certainly much more frequently used than 'to come'.

Given the historical distribution of the venitive passive in Carinthian Slovene, together with its complete absence in Slovene proper, it can certainly be traced back to Romance influence here, just like in Alemannic and in Carinthian Bavarian. However, it remains unclear whether it entered Carinthian Slovene by direct contact with the Romance population or rather indirectly by means of the overall contact with German (Carinthian Bavarian), together with other instances of German-based linguistic phenomena, like particle verbs and word order.

Be that as it may, the Carinthian-Slovene come construction does not seem a good candidate for an Alpine venitive passive either, due to its weak position and its low frequency. If, however, already rare occurrences are considered enough for making such a claim, then it can certainly play its role. ${ }^{11}$

\subsection{The venitive passive in Resian}

Before addressing the question of a possible contribution of Resian to an Alpine venitive passive, a few words should be said about the distribution of the come passive in Italian, in order to be able to refer to the effect of language contact in the Resian grammar (and in Molise Slavic below).

10 The bo constructions in this example refer to the future. So, obviously, the bo passive is ambiguous with respect to present and future events, which further underlines its connection with German werden.

11 Actually, an anonymous reviewer observes that in Slavic languages (and in many others as well) the passive altogether usually has a weak position and is rare. Thus, even rare occurrences might be indicative if there is reason to assume no other grammatical interpretation. 
In Italian, only the simple forms of the auxiliary venire 'to come' are used in (eventive) passive constructions; see the examples in (5), referring to the present (5a), the future (5b) and the simple past (5c). Instead of its compound forms, referring to the present perfect, the past perfect, the past future and so on, the traditional auxiliary essere 'to be' has to be used, in spite of its ambiguity for eventive and stative passive; for example, the esse present perfect is used in (5d) instead of the incorrect venitive construction in (5e). ${ }^{12}$
a. Il portone viene chiuso. (Aux to come, present) 'The door is (being) closed.'
b. Il portone verrà chiuso. (Aux to come, future)
c. Il portone venne chiuso. (Aux to come, simple aoristic past)
d. Il portone è stato chiuso. (Aux to be, present perfect)
e. $\quad$ Il portone è venuto chiuso.

Just like the German-based linguistic enclaves in Italy (and contrary to Bavarian proper), the Slavic micro-varieties in north-eastern and southern Italy, spoken in areas of total language contact by exclusively bilingual speakers, use the venitive passive to a greater extent. As for the north-eastern province of Friuli-Venezia Giulia we concentrated our research on the Slovene-based variety, spoken in the Resia valley, known as the Resian micro-language. ${ }^{13}$

Resian is nowadays the native language of approximately 1,000 speakers. Their ancestors entered the Resia Valley from Carinthia perhaps as early as the 7th but more probably in the 10th century. The valley belonged to the Patriarchate of Aquileia till 1420, when it became part of the Venetian Republic. From then on, the Resia Valley shared the political history of the Friuli region. At the beginning of the 19th century it was disputed between Napoleon and the Habsburgs. Later on, after half a century of Austrian domination, the Friuli region (including Resia) was annexed by Italy in 1866.

Thus, the Resian micro-language not only underwent a period of (Austrian) German linguistic contact, but has also been under Romance influence for

12 The venitive passive is used also in Friulian but, unlike in Italian, it is not admitted in the simple past (passato remoto); for more details see Marchetti (1967: 156-157). It is important to note that the venitive passive seems to have originated in Venetian (Rohlfs 1969: 128-129), from where it possibly spread not only to the neighboring Romance varieties, but even to Old Albanian (see on this point Breu forthcoming: chapter 6.3).

13 Besides Resian, there are other Slovene-based varieties further to the south, namely the tersko and the nadiško dialects (spoken respectively in the nearby Valli del Torre and Valli del Natisone), and the Slovenian vernaculars spoken in the provinces of Gorizia and Trieste. For more details about the historical and linguistic situation of these varieties, see Spinozzi-Monai (2015) and Benacchio (2002: 63-70). 
centuries, in particular the influence of Friulian, Venetian and - after the second half of the 19th century - standard Italian. Nowadays all the native speakers are bilingual, mastering Resian and Italian alike. As for the linguistic contact of the minority language with Slovene varieties in the last centuries (both in the north and in the east), it has been extremely low, almost irrelevant. ${ }^{14}$

Just like other Slavic languages, Resian has two traditional possibilities for expressing passive meaning, the esse passive and the reflexive passive. In addition, there are also examples of a venitive passive, not very frequent, but contrary to Carinthian Bavarian and Carinthian Slovene accepted by all speakers and still used spontaneously and even in writing.

The Resian venitive passive is formed by means of the auxiliary prït (PFv)/ parhajat (IPFV) 'come' + PPP of the lexical (perfective) verb. ${ }^{15}$ A typical example is (6), referring to an actual process in the present with the help of the imperfective auxiliary and showing that the venitive passive, like the esse passive (and unlike the reflexive passive), allows for an agent. It is expressed by the preposition od 'from' + genitive case. For the sake of comparison, see also its Italian translation.

(6) a. Resian

$\begin{array}{lllll}\text { Injän tve } & \text { dugave ni= } & \text { parhaä̈ } \\ \text { now your debts } & \text { 3PL.NOM } & \text { come:IPFV.PRS.3PL } \\ \text { zapïsane } & \text { od avokatä. } & \\ \text { record:PPP.NOM.PL.M by lawyer:SG.GEN.M } & \end{array}$

b. Italian

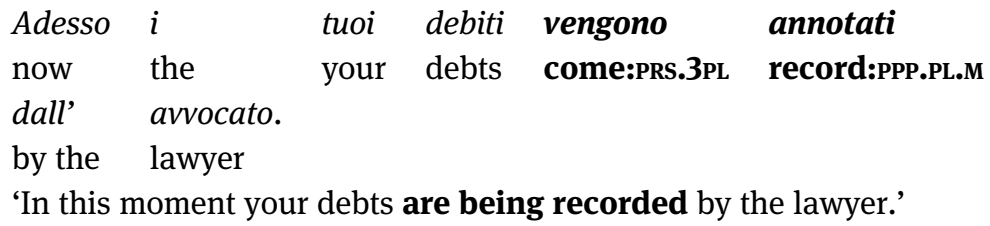

14 Resian is not a homogeneous entity, but consists of four major varieties, spoken in four different villages (San Giorgio, Gniva, Oseacco and Stolvizza). Despite their divergences on every linguistic level, in the domain of the passive no relevant differences have been noted. Therefore, the examples presented here, belonging to different varieties of Resian, have not been marked with respect to the place of their origin. For more information on Resian and its historical-linguistic development, see, for instance, Steenwijk (1992: 1-3) and Šekli (2018). In addition, note that the first collection of Resian texts, edited by Baudouin de Courtenay (1895), presents important linguistic material from the end of the 19th century.

15 Just like other verbal lexemes in Resian and in Slavic in general, the auxiliary 'to come' is expressed by two verbs forming an aspectual pair, one of them being imperfective (IPFV), the other one perfective (PFV). 
The same is true for the expression of habitual passive events in the present as in (7), referring to periodical meetings of schoolchildren, and (8).

(7) a. Resian

$\begin{array}{lllllll}\text { enu } & \text { jsö } & \text { to } & \text { parhaja } & \text { nerëd } & \text { po furlenski } \\ \text { and } & \text { this } & \text { it } & \text { come:IPFV.PRS.3sG } & \text { make:PPP } & \text { on Friulian } \\ \text { enu } & p u & n \text { ns }^{16} & & & & \\ \text { and } & \text { on } \text { us } & & & & \end{array}$

b. Italian

$\begin{array}{llllll}e & \text { questo } & \text { viene } & \text { fatto } & \text { in friulano } \\ \text { and } & \text { this } & \text { come:PRs.3sg } & \text { make:PPP.sG.M } & \text { in Friulian } \\ e & \text { in } & \text { resiano } & & & \\ \text { and } & \text { in } & \text { Resian } & & & \end{array}$

and in Resian

'and this is done in Friulian and in Resian'

(8) a. Resian

Ite dni je te Festival, ka sprawja ite $k a$

those days is that Festival, that gathers those that

pravijo pravice ano isö to parhaja narëd

tell stories and this it come:IPFV.PRs.3sg make:PPP

wže 15 lit. $^{17}$

already 15 years

b. Italian

In quei giorni c'è il Festival che riunisce coloro

in those days there is the Festival that gathers those

che raccontano le favole e ciò viene

who tell the stories and this come: PRs.3sG

fatto già da quindici anni.

make:PPP.sG.M already from fifteen years

'In those days there is the Festival that gathers those who tell stories and this has been done already for fifteen years.'

One woman accepted the use of the perfective auxiliary to describe a "habitual" situation in the present in (9). However, this was not her first choice and seems an exceptional use.

16 The past participle narëd 'done' (whose infinitive is the perfective verb naredit) is indeclinable. 17 This example is taken from Novi Matajur, a weekly newspaper, containing also texts in Slovene vernaculars spoken in the province of Udine (Italy). 
(9) a. Resian

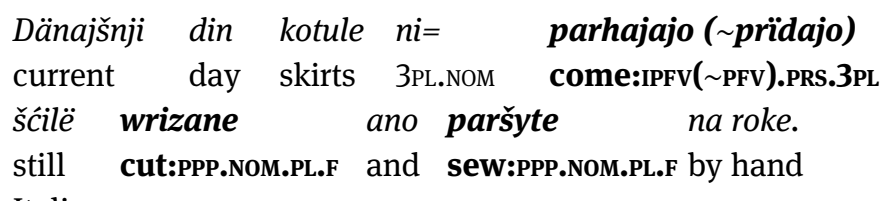

b. Italian

$\begin{array}{llllll}\begin{array}{l}\text { Al giorno d'oggi le } \\ \text { nowadays }\end{array} \quad \text { the } & \text { skirts } & \begin{array}{l}\text { vengono } \\ \text { come:PRs.3PL }\end{array} & \begin{array}{l}\text { ancora } \\ \text { still }\end{array} & \begin{array}{l}\text { tagliate } \\ \text { cut:PPP.PL.F }\end{array} \\ e \quad \text { cucite } & a & \text { mano. } & & \\ \text { and sew:PPP.PL.F } & \text { by } & \text { hand } & & \end{array}$

'Nowadays skirts are still cut and sewed by hand.'

Habitual events in the past, however, use the imperfective perfect of the auxiliary, which is formed by means of the verb bet 'to be' at the present tense + imperfective l-participle of 'to come'; see example (10). It should be kept in mind that in Resian, the imperfective perfect corresponds to the Italian imperfect, as the Resian imperfect has become obsolete, except for irreality (Pila in print). ${ }^{18}$

(10) a. Resian

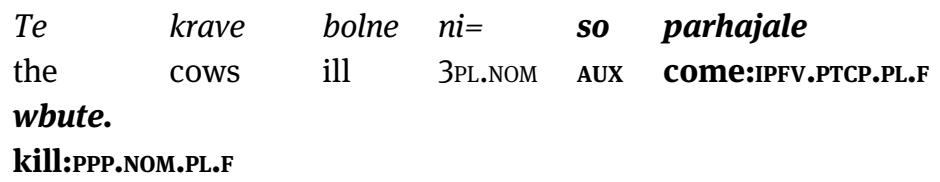

b. Italian

$\begin{array}{lllll}\text { Le } & \text { mucche } & \text { ammalate } & \text { venivano } & \text { uccise. } \\ \text { the } & \text { cows } & \text { ill } & \text { come:IPRF.3PL } & \text { kill:PPP.PL.F }\end{array}$

'The ill cows used to be killed.'

In Resian, the perfective perfect of the auxiliary functionally corresponds to the Italian perfect (passato prossimo) and should therefore be excluded from the venitive perfect. But interestingly enough, such a perfective perfect is nevertheless used in Resian for unique completed events in the past, though only by a few (old) speakers, see example (11). This usage could be explained by an internal analogical expansion from the imperfective perfect (corresponding to the imperfect) to the perfective perfect. ${ }^{19}$

18 A different situation can be observed in Molise Slavic, where the imperfect is still alive (and in aspectual opposition to the perfect) and can combine (with different meanings) both with perfective and imperfective aspects (see 3.3).

19 At the present stage of research, there is no example available with a perfective venitive passive in the past referring to a repeated state of affairs. 
(11) a. Resian

Roža so paršla šinkana wsa.

flowers Aux come:PFV.PTCP.PL.F give:PPP.PL.F all:PL.F

b. Italian

I fiori sono stati ( ${ }^{*}$ sono venuti) regalati tutti. ( ${ }^{*}$ perfect)

the flowers be:PRF.PL.M give:PPP.PL.M all:PL.M

'All the flowers were given (as a present).'

Unique completed events in the future require the periphrastic future of the perfective auxiliary prït 'to come' as in (12).

(12) a. Resian

$\begin{array}{llll}\text { Zütra ćë(jö) } & \text { prït } & \begin{array}{l}\text { zapïsane } \\ \text { record:PPP.PL.M }\end{array} & \begin{array}{l}\text { wse } \\ \text { all }\end{array} \\ \text { tomorrow Aux } & \text { come:PFV.INF } & \\ \text { tve dugave. } & & & \\ \text { your debts } & & \end{array}$

b. Italian

Domani verranno annotati tutti $i$ tuoi debiti.
tomorrow come:Fut.3PL record:PPP.PL.m all the your debts
'Tomorrow all your debts will be recorded.'

Some examples of the venitive passive have been recorded also in the historical present. In this case it refers to single completed states of affairs which took place in the past. The auxiliary appears in its imperfective present as in (13).

(13) a. Resian

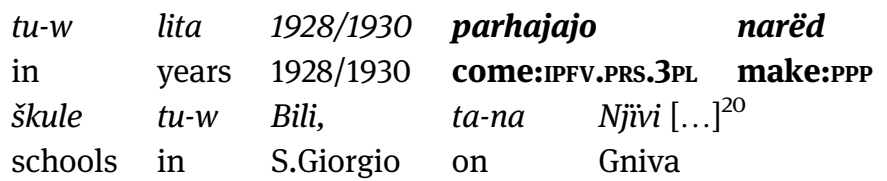

b. Italian

Negli anni 1928/1930 vengono fatte le scuole

in the years 1928/1930 come:Prs.3PL make:PPP.PL.F the schools

a S. Giorgio, a Gniva...

in S. Giorgio in Gniva...

'In the years 1928/1930 are built the schools in S. Giorgio and Gniva ...'

20 This example comes from the Internet (access: August 28, 2019). http://www.comune. resia. ud.it/index.php?id=1427\&L=4. 
Example (14), from Baudouin de Courtenay (1913: §427), shows that venitive passives most likely already existed in Resian more than a century ago. It is worth noting that in the following example the auxiliary appears in the PFV aspect, as was the case also in (11) and (12). Nevertheless, while in (11) and (12) the auxiliary verb appeared in the past and in the future tenses, in (14) it stays in the present (with non-actual, iterative meaning). Thus, it might be concluded that the use of 'come' in its perfective variant is possible in all simple tenses.

(14) a. Resian

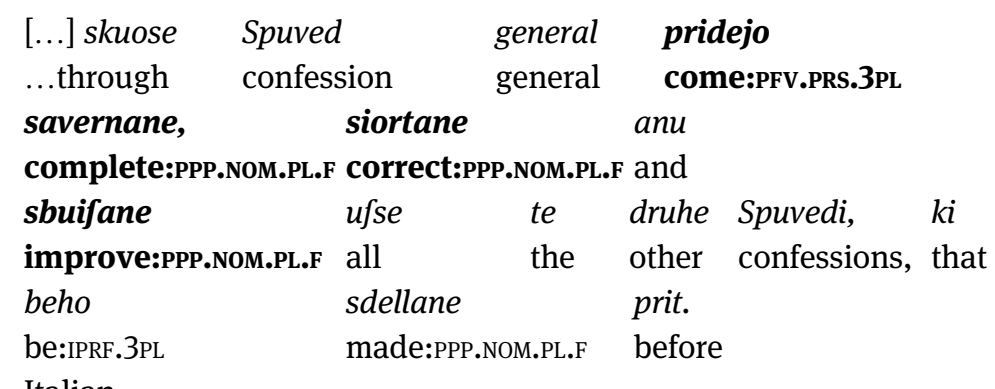

b. Italian

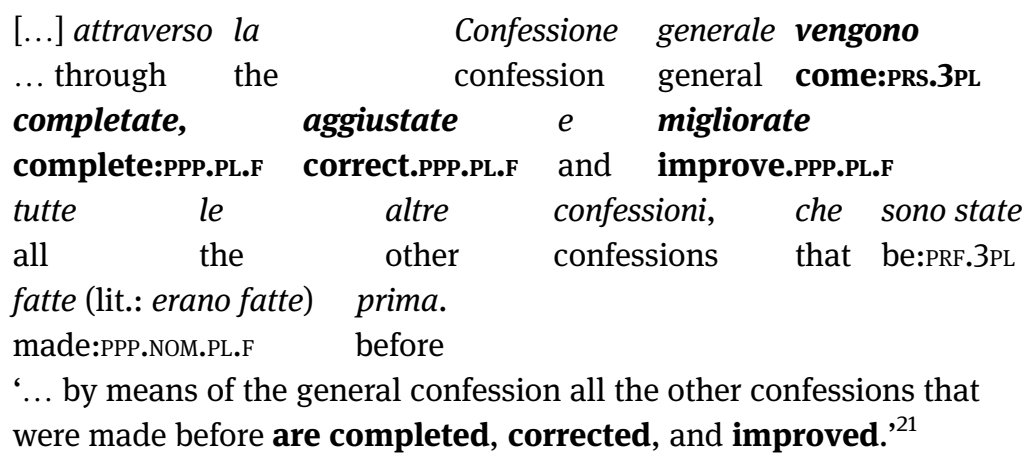

In Baudouin's glossary of the tersko dialect, examples like pride štampano 'is printed', literally “comes printed” (Spinozzi-Monai 2009: §3584), show that the venitive passive has entered this vernacular too. However, in Baudouin's collection of nadiško texts (Baudouin de Courtenay 1988), there is no occurrence of this construction. It could well be that it is completely absent in the nadiško dialect, but

\footnotetext{
21 In this work Baudouin de Courtenay publishes a number of sermons going back to the middle of the 19th century, whose author was probably a priest from Moggio (outside Resia); according to Baudouin he nevertheless mastered Resian like a native speaker (Baudouin de Courtenay 1913: 113). No examples of a venitive passive exist, either in Baudouin's Materialien (1895) or in the Catechism of the end of the 18th century (Baudouin de Courtenay 1894), the most ancient document written in Resian.
} 
this should be verified in contemporary language. If this assumption holds true, it could be due to the different situation of linguistic contact between tersko and nadiško. The latter could have rejected the Romance model of a venitive passive, due to its closer contact with standard Slovene.

Interestingly enough, Resian copied under Romance influence not only the venitive passive but also the so-called "andative passive" with its modal (deontic) component. The andative passive, that is, a passive involving the verb 'to go' (tet in Resian) as auxiliary + the past participle of the lexical verb, is quite common in Italian, where sentences like la bottiglia va chiusa 'the bottle has to be closed' express the necessity of an action to be performed. Unlike the venitive and the esse passive the Resian andative passive seems not to accept an agent. In Resian the meaning of flajša na gre zaǵana corresponds exactly to the given Italian sentence. Nevertheless, some (very few) native speakers admit a secondary reading, 'the bottle is being closed', thus interpreting it as an ongoing passive process. ${ }^{22}$ This holds true for repeated actions as well. The secondary reading is possible because of the ambiguity of tet 'to go', which in its imperfective form or use (in those languages in which it is biaspectual) admits in most Slavic languages the additional meaning 'to come'. 23

In Italian the andative passive can be used with deontic meaning in the past (=imperfect) tense, too, as in la bottiglia andava chiusa 'the bottle had to be closed'. ${ }^{24}$ This is contrary to Resian, where the past tense of the auxiliary tet generally does not combine with a PPP. It is, however, accepted by some informants in combination with the PPP of verbs expressing "consumption" or "negative outcome” - 'to destroy', 'to lose', etc. - as a predicate conveying a definitive, irreversible meaning. Thus, the sentence Lïbri ë šol zübjën means exclusively 'the book is gone lost' and corresponds to the Italian il libro è andato perduto. With

22 In this case an agent seems to be possible.

23 It should be noted that in Resian this ambiguity is rather weak. This micro-language (like standard Slovene) tends to differentiate the 'go' and 'come' meanings, which are normally expressed respectively through the forms tet IPFV/PFv and parhajat IPFv/prït PFv. Nevertheless, Resian examples like Le, hre slötä!, literally "Look, is coming bad weather!”, with the verb tet 'to go' in the additional meaning 'to come' are possible, though not very frequent. In Molise Slavic this ambiguity is stronger than in Resian, because here the imperfective verb hot (grem: PRs.1sG) is completely ambiguous between 'to go' and 'to come'; see Section 3.3 below.

24 For further information on the construction involving the verb 'to go' + past participle in Italian see for instance Bertinetto (2001: 150-151), Salvi and Vanelli (2009: 70), and Sansò and Giacalone Ramat (2016). Bertinetto assigns two possible readings to the considered structure: the deontic (la bottiglia va chiusa) and the "pure passive" (il libro è andato perduto), the latter being characterized by the lack of any modal meaning. Unlike Bertinetto, Salvi and Vanelli do not consider sentences like il libro è andato perduto as passive. 
respect to the andative passive in Resian, further research has to be done in the future.

\subsection{The venitive passive in Molise Slavic}

For the sake of comparison, in this section another Slavic micro-language will be dealt with, Molise Slavic, which clearly has nothing to do with a potential "Alpensprachbund". The Molise Slavic enclave in the region of Molise in southern Italy, with only three small villages remaining, has its origins in the immigration of people from the Serbo-Croatian dialect continuum in the 16th century, more precisely from the Neretva Valley in Hercegovina. Language contact with local Romance varieties, and since the second half of the 19th century also with standard Italian, has changed the grammatical and lexical structure of this Slavic variety in many respects. ${ }^{25}$ So, it is no wonder that we find here, too, a contact-induced passive formed with the help of the auxiliary 'to come', in this case realized as a suppletive aspectual pair: dokj PFv/grem IPFV.

In Molise Slavic, just like in Resian, the venitive passive is used besides the polysemic esse passive, in order to differentiate between eventive passives and resultative states (stative passive). In principle, the reflexive passive could fulfill the same task. But when the agent of an eventive passive is expressed, the venitive passive is obligatory. The exclusion of an explicit agent in the reflexive passive could be an effect of language contact, as many Slavic languages allow it, for example Russian, though Slovene and Modern Croatian do not. In any case, this is essentially the same situation as in Italian.

The Molise Slavic venitive passive is possible in the present, the future and the imperfect, but it is excluded from the perfect, again just like in Italian. ${ }^{26}$ This exclusion of the venitive passive from the perfect, however, differentiates this micro-language from Resian. This is due to the full conservation of the imperfect in Molise Slavic, allowing for an exact copy of the imperfect-perfect opposition in all respects. On the other hand, the venitive passive has been integrated completely in the Molise Slavic aspect system - that is, when referring to unique processes, only the passive of imperfective verbs is possible. The perfective present and imperfect of the venitive passive are restricted to iterative and habitual events.

25 For more information on Molise Slavic see, for example, Breu (2017) and the classical work of Rešetar (1911).

26 For the different ways of expressing the passive in Molise Slavic, especially including the venitive passive, see Breu and Makarova (2019). Again, I am grateful to Walter Breu, Konstanz, for informing me about some important details and for the discussion of the examples. 
Example (15) shows an eventive passive, presented as a unique process in the imperfective present, while example (16) expresses the same case referring to the past. In this case we find the imperfective imperfect.

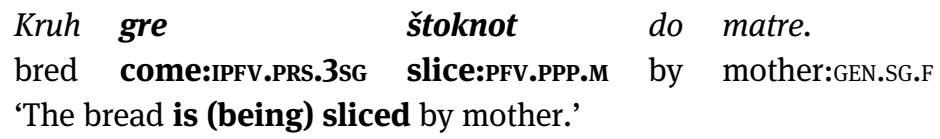

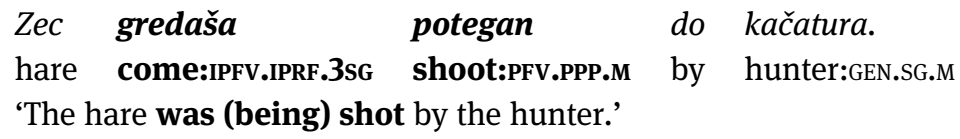

Just like in Italian, the venitive passive may also express habitual or repeated situations as in (17).

$$
\begin{array}{lllll}
\text { Magina gredaša } & \text { sfedni vržana } & \text { naza hiže. } \\
\text { car } & \text { come:IPFv.IPRF.3sg always put:PFv.PPP.F behind house } \\
\text { 'The car was always put behind the house.' } &
\end{array}
$$

The polysemy for unique processes and habitual events exists only with the imperfective forms of the auxiliary, while the perfective auxiliary only expresses habitual situations. Compare example (18), where the perfective imperfect dodjaše is restricted to a habitual reading, to example (19), where its imperfective counterpart gredaše expresses the passive both as a unique process and as a habitual iteration.

$\begin{array}{llll}\text { Ona hladnja dodjaše } & \text { pokrena } & \text { kano } \\ \text { that heap come:PFV.IPRF.3sg } & \begin{array}{l}\text { cover:PFV.PPP.F } \\ \text { like }\end{array} \\ \text { tito do hiže. } & & \\ \text { roof of house } & & \end{array}$

\begin{tabular}{|c|c|c|c|}
\hline Ona & hladnja & gredaše & $\begin{array}{l}\text { pokrena } \\
\text { cover:PFy.PPP.F }\end{array}$ \\
\hline titc & do hiže. & & \\
\hline
\end{tabular}

'That heap used to be covered like the roof of a house.'

'That heap used to be covered ( was being covered) like the roof of a house.'

Thus, Molise Slavic allows for a disambiguation between single and repeated situations by means of the Slavic verbal aspect, unlike Italian, where the present and the imperfect of the venitive passive are always ambiguous in this respect. 
The perfective imperfect dojaša vržana (and likewise the perfective present doje vržana) in example (20), contrary to its polysemic Italian translation veniva messa and in contrast to its imperfective counterpart gredaša vržana in (17) (and the imperfective present gre vržana), cannot refer to a unique process, but expresses always an iteration.

(20) a. Molise Slavic

$\begin{array}{lllll}\text { Magina } & \text { dojaša } & \text { vržana } & \text { naza } & \text { hiže. } \\ \text { car } & \text { come:PFV.IPRF.3sg } & \text { put:PFV.PPP.F } & \text { behind house }\end{array}$

b. Italian

La macchina veniva messa dietro la casa.

'The car used to be put behind the house.'

So, Molise Slavic, while copying the Italian model of a venitive passive and even respecting its exclusion from the perfect, developed a means of differentiation going beyond the possibilities of the Italian model. It originated in the general function of the perfective imperfect (and present) expressing iteration/habituality (Breu 2014: 337-340).

Molise Slavic, like Resian, copied not only the venitive passive from Italian but also the "andative passive" with its deontic component. As was mentioned above, there is a problem with this, as in most Slavic languages in the imperfective aspect 'to go' and 'to come' coincide. As a consequence a phrase like funaštra gre tvorena may mean both 'the window is being closed' (Aux grem 'to come') and 'the window has to be closed' (Aux grem 'to go'). The same is true for example (21), without an explicit adverb of frequency. All in all, there are four homonymous passive readings: a single process (a) or iteration (b) of the venitive type as well as a single event (c) or iteration (d) of the andative deontic type. The Italian translations are ambiguous with respect to the unique and the iterative readings, but they contrast in having different auxiliaries.

(21) Molise Slavic: Magina gre vržana naza hiže.

a. 'The car is being put behind the house'.

b. 'The car is always/usually put behind the house'.

Italian: La macchina viene messa dietro la casa.

c. 'The car has to be put behind the house'.

d. 'The car has always/usually to be put behind the house.'

Italian: La macchina va messa dietro la casa.

The same would be true for the imperfective imperfect with the auxiliary gredaša, meaning both 's/he came' and 's/he went'. But the perfective imperfect dojaša, meaning only 's/he came', unambiguously expresses an iteration of the venitive 
type. It seems the perfective imperfect pojaša 's/he went' does not form an andative passive at all.

Summing up, it seems justifiable to claim that the venitive passive is well integrated into the Molise Slavic verb system. Just like in Resian, it was copied from the Romance model, in order to distinguish between the eventive passive and the stative passive, which traditionally are expressed by means of the auxiliary bit 'to be'. Just like in Italian and Resian, it fills a gap in being able to explicitly express the agent, contrary to the reflexive eventive passive.

On the other hand, there are some characteristic differences between the venitive passive in Molise Slavic and Italian, resulting from the differences of their grammatical systems:

1. Due to its twofold aspect system, Molise Slavic is able to differentiate between the unique processual and the habitual venitive passive in the imperfect and in the present.

2. Due to the ambiguity of the imperfective auxiliary grem 'go, come', the Molise Slavic construction may express ambiguously the simple eventive passive and the deontic passive.

\section{Conclusion}

The venitive passive never existed in most parts of Bavarian (in the central Alps, or north of the Alps). Unlike in Alemannic, traces of it exist only in the southernmost parts (Southern Carinthia, East and South Tyrol). Nowadays, it is almost absent in those regions outside the areas of persistent, direct Romance influence. The same seems to be true for the Slavic (Slovene) dialects in Southern Carinthia. The venitive passive is found, however, in all Germanic (Alemannic and Bavarian) and Slavic (geographically isolated) linguistic enclaves in northern and southern Italy, with their strong, everyday contact with Romance varieties.

The overall development of a venitive passive goes back to Italian (Romance) influence. This is especially true for the Slavic minority languages in total language contact, that is, Resian and Molise Slavic, where it has entered the core grammar. Given the situation of the venitive passive in Bavarian on the one hand and the Slavic micro-languages on the other, it seems to speak not for an all-embracing “Alpensprachbund", but rather for the strong influence exerted by dominant Romance varieties on the minority languages in Italy in the field of grammar. 


\section{Abbreviations}

$\begin{array}{ll}\text { AUX } & \text { auxiliary } \\ \text { F } & \text { feminine } \\ \text { FUT } & \text { future } \\ \text { GEN } & \text { genitive } \\ \text { INF } & \text { infinitive } \\ \text { IPFV } & \text { imperfective } \\ \text { IPRF } & \text { imperfect } \\ \text { NOM } & \text { nominative } \\ \text { M } & \text { masculine } \\ \text { PFV } & \text { perfective } \\ \text { PL } & \text { plural } \\ \text { PPP } & \text { passive past participle } \\ \text { PRF } & \text { perfective } \\ \text { PRS } & \text { present } \\ \text { PTCP } & \text { participle } \\ \text { REFL } & \text { reflexive } \\ \text { SG } & \text { singular }\end{array}$

\section{References}

Bajec, Anton, Rudolf Kolarič \& Mirko Rupel. 1971. Slovenska Slovnica. Ljubljana: DZS.

Baudouin de Courtenay, Jan. 1894. Il catechismo resiano (con una prefazione del dott. G. Loschi). Udine: Tipografia del Patronato.

Baudouin de Courtenay, Jan. 1895. Materialy dlja južnoslovjanskoj dialektologii i ètnografii. Sanktpeterburg: I. Rez'janskie teksty.

Baudouin de Courtenay, Jan. 1913. Christjanske Uzhilo. S.-Peterburg: Tipografija Imperatorskoj Akademij Nauk.

Baudouin de Courtenay, Jan. 1988. Materiali IV. Per la dialettologia e l'etnografia slava meridionale. Testi popolari in prosa e in versi raccolti in Val Natisone nel 1873. Inediti pubblicati a cura di Liliana Spinozzi-Monai. Trieste: EST.

Bellmann, Günter. 1998. Zur Passivperiphrase im Deutschen. Grammatikalisierung und Kontinuität. In Peter Ernst \& Franz Patocka (eds.), Deutsche Sprache in Raum und Zeit, 241-269. Wien: Edition Praesens.

Benacchio, Rosanna. 2002. I dialetti sloveni del Friuli tra periferia e contatto. Udine: Società Filologica Friulana.

Bertinetto, Pier Marco. 2001. Il verbo. In Lorenzo Renzi, Gianpaolo Salvi \& Cardinaletti Anna (eds.), Grande grammatica italiana di consultazione II. Bologna: II Mulino.

Breu, Walter. 2003. Bilingualism and linguistic interference in the Slavic-Romance contact area of Molise (Southern Italy). In Regine Eckardt, Klaus von Heusinger \& Christoph Schwarze (eds.), Words in time. Diachronic semantics from different points of view, 351-373. Berlin \& New York: De Gruyter. 
Breu, Walter. 2014. = Val'ter Broj. 2014. Funkcii nastojaščego i imperfekta soveršennogo vida $\mathrm{i}$ perfekta nesoveršennogo vida v molizsko-slavjanskom mikrojazyke. Scando-Slavica 60(2). 322-351.

Breu, Walter. 2017. Slavische Mikrosprachen im absoluten Sprachkontakt. Band I. Moliseslavische Texte aus Acquaviva Collecroce, Montemitro und San Felice del Molise. Wiesbaden: Harrassowitz.

Breu, Walter. forthcoming. Romance in contact with Albanian. In Francesco Gardani \& Michele Loporcaro (eds.), Oxford encyclopedia of romance linguistics. Oxford: Oxford University Press.

Breu, Walter \& Anastasia Makarova. 2019. Typologie des Passivs im Moliseslavischen: Bewahrung, Umbau und Innovation im totalen slavisch-romanischen Sprachkontakt. In Bernhard Brehmer \& Holger Kuße (eds.), Slavistische Linguistik 2016/2017, Wiener Slawistischer Almanach 83, 7-60. Frankfurt am Main etc: Lang.

Bucheli Berger, Claudia. 2005. Passiv im Schweizerdeutschen. Linguistik Online 24(3). 1-25.

Dal, Ingerid \& Hans-Werner Eroms. 2014. Kurze deutsche Syntax auf historischer Grundlage. Berlin \& Boston: De Gruyter Mouton.

Gaeta, Livio. 2018. Im Passiv sprechen in den Alpen. Sprachwissenschaft 43(2). 221-250.

Giacalone Ramat, Anna. 2000. On some grammaticalization patterns for auxiliaries. In Charles Smith John \& Delia Bentley (eds.), Historical linguistics 1995. Vol. 1, General issues and non-Germanic languages, 125-154. Amsterdam \& Philadelphia: John Benjamins.

Giacalone Ramat, Anna. 2017. Passives and constructions that resemble passives. Folia Linguistica 51(38). 149-176.

Giacalone Ramat, Anna \& Andrea Sansò. 2014. Venire ('come') as a passive auxiliary in Italian. In Maud Devos \& Jenneke van der Wal (eds.), 'COME' and 'GO' off the beaten grammaticalization path, 21-44. Berlin \& Boston: De Gruyter Mouton.

Heine, Bernd. 2014. Areal tendencies in derivation. In Rochelle Lieber \& Pavol Štekauer (eds.), Oxford handbook of derivational morphology, 767-776. Oxford: Oxford University Press.

Heine, Bernd \& Tania Kuteva. 2010. Contact and grammaticalization. In Raymond Hickey (ed.), The handbook of language contact, 86-105. Chichester: Wiley.

Herrity, Peter. 2000. Slovene, a comprehensive grammar. London \& New York: Routledge.

Isačenko, Aleksander V. 1939. Narečje vasi sele na Rožu. Ljubljana: Znanstveno Društvo.

Jodlbauer, Ralph. 1996. Die Kärntner Slowenen. In Robert Hinderling \& Ludwig M. Eichinger (eds.), Handbuch der mitteleuropäischen Sprachminderheiten, 119-165. Narr: Tübingen.

Kotin, Michail. 1998. Die Herausbildung der grammatischen Kategorie des Genus verbi im Deutschen. Eine historische Studie zu den Vorstufen und zur Entstehung des deutschen Passiv-Paradigmas. Hamburg: Buske.

Lepschy, Anna L. \& Giulio Lepschy. 1977. The Italian language today. London: Hutchinson \& Co.

Lessiak, Primus. 1903. Die Mundart von Pernegg in Kärnten. Beiträge zur Geschichte der deutschen Sprache und Literatur 28. 1-227.

Marchetti, Giuseppe. 1967. Lineamenti di grammatica friulana. Udine: Società filologica friulana. Maurer-Lausegger, Herta. 1992. Das Slowenische in Kärnten in soziolinguistischer Sicht. Wiener Slavistisches Jahrbuch 38. 89-106.

Mayerthaler, Eva \& Willi Mayerthaler. 1990. Aspects of Bavarian syntax, or "any language has at least two parents”. In Jerold Edmondson, Feagin Crawford \& Peter Mühlhäusler (eds.), Development and diversity. Language variation across time and space. A festschrift for C.-J. $N$. Bailey, 371-429. Dallas: Summer Institute of Linguistics/University of Texas at Arlington. 
Mayerthaler, Willi. 1986. Über die Nichtverschiebung des anlautenden $p$ - im Bairischen (Fortsetzung). Österreichische Namenforschung 14(1/2). 7-80.

Mayerthaler, Willi, Günther Fliedl \& Christian Winkler. 1995. Der Alpen-Adria-Raum als Schnittstelle von Germanisch, Romanisch und Slawisch. Tübingen: Narr.

Neweklowsky, Gerhard. 2013. Der Gailtaler slowenische Dialekt. Klagenfurt etc: Drava.

Pila, Malinka. 2019. Passivo e aspetto verbale in resiano, russo e sloveno. In Iliana Krapova, Svetlana Nistratova \& Luisa Ruvoletto (eds.), Studi di linguistica slava. Nuove prospettive $e$ metodologie di ricerca (Atti del VI Incontro di Linguistica slava, Venezia 20-22.9.2018)x, 439-451. Venezia: Edizioni Ca' Foscari. Available at: https://edizionicafoscari.unive.it/it/ edizioni4/libri/978-88-6969-369-4/passivo-e-aspetto-verbale-in-resiano-russo-e-slove/.

Pila, Malinka. Il periodo ipotetico in resiano (in confronto con lo sloveno). In Monica Genesin, Karl Gerhard Hempel \& Kahl Thede (eds.), Endangered linguistic varieties and minorities in Italy and the Balkans. Wien: VLACH, in print.

Pronk, Tijmen. 2009. The Slovene dialect of Egg and Potschach in the Gailtal, Austria. Amsterdam \& New York: Rodopi.

Ramat, Paolo. 1998. Typological comparison and linguistic areas: Some introductory remarks. Language Sciences 20(3). 227-240.

Rešetar, Milan. 1911. Die serbokroatischen Kolonien Süditaliens. Wien: Kaiserliche Akademie.

Rohlfs, Gerhard. 1969. Grammatica storica della lingua italiana e dei suoi dialetti. Sintassi e formazione delle parole. Torino: Einaudi.

Salvi, Giampaolo \& Laura Vanelli. 2009. Nuova grammatica italiana. Bologna: Il Mulino.

Sansò, Andrea \& Anna Giacalone Ramat. 2016. Deictic motion verbs as passive auxiliaries: The case of Italian andare 'go' (and venire 'come'). Transactions of the Philological Society 114. $1-24$.

Schwarze, Christoph. 2009. Grammatica della lingua italiana. Roma: Carocci.

Serianni, Luca. 1988. Grammatica italiana. Italiano comune e lingua letteraria. Torino: UTET.

Spinozzi-Monai, Liliana. 2009. Il Glossario del dialetto del Torre di Jan Baudouin de Courtenay. Udine: Consorzio Universitario del Friuli.

Spinozzi-Monai, Liliana. 2015. Sloveno. In Sabine Heinemann \& Luca Melchior (eds.), Manuale di linguistica friulana, 245-273. Berlin \& Boston: De Gruyter Mouton.

Steenwijk, Han. 1992. The Slovene dialect of Resia. San Giorgio, Amsterdam etc: Rodopi.

Šekli, Matej. 2018. Slovenski jezik v Reziji. In Matej Šekli \& Andreja Žele (eds.), Slovenistika in slavistika v zamejstvu - Videm. Ljubljana: Zveza društev Slavistično društvo Slovenije.

Thieroff, Rolf. 1994. Vorgangs- und Zustandspassiv in romanischen und germanischen Sprachen. STUF - Language Typology and Universals 47(1). 37-57.

Vogel, Petra Maria. 2014. Das unpersönliche Passiv. Eine funktionale Untersuchung unter besonderer Berücksichtigung des Deutschen und seiner historischen Entwicklung. Berlin \& Boston: De Gruyter Mouton.

Wiemer, Björn. 2011. The grammaticalization of passives. In Bernd Heine \& Heiko Narrog (eds.), The Oxford handbook of grammaticalization, 1-9. Oxford: Oxford University Press. Online publication date Sep 2012. https://doi.org/10.1093/oxfordhb/9780199586783.013.0043.

Wiesinger, Peter. 1989. Zur Passivbildung mit kommen im Südbairischen. In Wolfgang Putschke, Werner Veith \& Peter Wiesinger (eds.), Dialektgeographie und Dialektologie, 256-268. Marburg: Elwert. 